\title{
Microfinance: To analyse the trend and magnitude of flow of credit in Odisha
}

\author{
SEEDARI UJWALA RANI, JYOTI PRAKASH SETHY, PRAMOD KUMAR AND MODEM RAVI \\ KISHORE
}

Received : 03.07.2016; Revised : 05.09.2016; Accepted : 20.09.2016

\begin{abstract}
Microfinance has evolved as a development approach to benefit the socially and economically underprivileged facing difficulty in accessing institutional finance. It is particularly attractive as a tool to help the poor, since it is widely seen as improving livelihoods, reducing vulnerability and fostering social as well as economic empowerment. Financial inclusion can be defined as delivery of banking services at an affordable cost to the vast sections of disadvantaged and low-income and it also covers various other financial services such as savings, insurance, payments and remittance facilities by the formal financial system to those who tend to be excluded like marginal farmers, agricultural labourers, artisans, members of the scheduled tribes and it also helps in accessing institutional credit through commercial banks, co-operative banks, RRBs, NABARD SHG-linkage, other self-help groups and credible microfinance institutions. Analysing secondary data through compound annual growth rate (CAGR), it has been observed that microfinance has emerged as the most effective and successful tool for financial inclusion and it has seen as beacons of hope to help eradicate poverty by providing credit to poor rural households. Microfinance has evolved as a development approach to benefit the economically underprivileged facing difficulty in accessing institutional finance.
\end{abstract}

KEY WORDS : (SHG) Self-help group, (NABARD) National bank for agriculture, Rural development, (CAGR) Compound annual growth rate, RRB (Regional rural bank), (RBI) Reserve bank of India

How to cite this paper : Rani, Seedari Ujwala, Sethy, Jyoti Prakash, Kumar, Pramod and Kishore, Modem Ravi (2016). Microfinance : To analyse the trend and magnitude of flow of credit in Odisha. Internat. J. Com. \& Bus. Manage, 9(2) : 234-241. DOI: 10.15740/HAS/ IJCBM/9.2/234-241. 